\title{
Юридический статус Суверенного Мальтийского ордена - ключевые вопросы, связанные с функциональной субъектностью
}

Prawnomiędzynarodowy status Suwerennego Zakonu Kawalerów Maltańskich węzłowe zagadnienia związane z suwerennością funkcjonalną

Legal and international status of the Sovereign Order of the Knights of Malta key issues related to functional subjectivity

\author{
KACPER MIROSŁAW MILKOWSKI \\ Mgr, Akademia Ekonomiczno-Humanistyczna w Warszawie \\ e-mail: kacpermilkowski@gmail.com, https://orcid.org/0000-0003-4367-0365
}

\begin{abstract}
Резюме: Вопросы, связанные с международной субъектностью, являются одними из наиболее обсуждаемых в доктрине. В то время как в правовых системах отдельных государств вопрос субъектности решается законодателями, в международном праве отсутствует аналогичная договорная норма. Таким образом, понятие и понимание субъектности - это вопрос, рассматриваемый в первую очередь представителями доктрины международного права. Предполагается, таким образом, что субъект международного права, должен обладать правоспособностью, то есть, способностью иметь права и обязанности, а также дееспособностью - возможностью распоряжаться своими правами и нести обязанности, что связано со способностью участия в международных отношениях. В доктрине принято считать, что специальным субъектом международного права является Суверенный Мальтийский орден. Целью данной статьи является обсуждение вопроса юридической субъектности Суверенного Мальтийского ордена. Автор проводит анализ субъектности ордена с точки зрения его способности действовать в сфере международного права, то есть поддерживать дипломатические и консульские отношения, участвовать в международных организациях, заключать договоры, предъявлять претензии и добиваться их, применяя мирные способы разрешения международных споров, нести международную ответственность, иметь собственное гражданство и территорию. Предположения проверялись с помощью двух методологических подходов: догматико-правового и формально-догматического.
\end{abstract}

Ключевые слова: международно-правовая субъектность, субъект международного права, Суверенный Мальтийский орден, экстерриториальность, международная правосубъектность, международное публичное право

Streszczenie: Zagadnienia związane z podmiotowością międzynarodową należą do najżywiej dyskutowanych w doktrynie. O ile w systemach prawnych poszczególnych państw kwestia podmiotowości rozstrzygana jest przez ustawodawców, o tyle w prawie międzynarodowym brakuje analogicznej normy traktatowej. Wobec tego pojęcie i rozumienie podmiotowości jest zagadnieniem rozpatrywanym przede wszystkim przez przedstawicieli doktryny prawa międzynarodowego. Przyjmuje się zatem, że podmiot prawa międzynarodowego musi legitymować się zdolnością prawną, czyli inaczej zdolnością do posiadania praw i obowiązków, oraz zdolnością do czynności prawnych - możliwością bezpośredniego zaciągania praw i obowiązków, co związane jest ze zdolnością występowania w stosunkach międzynarodowych. W doktrynie przyjmuje się, że specyficznym podmiotem prawa międzynarodowego jest Suwerenny Zakon Kawalerów Maltańskich. Celem niniejszej publikacji jest omówienie zagadnienia podmiotowości prawnomiędzynarodowej Zakonu Kawalerów Maltańskich. Wobec tego autor publikacji dokonuje analizy podmiotowości jednostki pod kątem jej zdolności do działania w sferze prawa międzynarodowego, tj. zdolności utrzymywania stosunków dyplomatycznych i konsularnych, 
uczestniczenia w organizacjach międzynarodowych, zawierania umów, występowania z roszczeniami i ich dochodzeniem poprzez odwołanie się do pokojowych sposobów załatwiania sporów międzynarodowych, ponoszenia odpowiedzialności międzynarodowej, posiadania własnego obywatelstwa oraz terytorium. Weryfikacja założeń nastąpiła poprzez dwa podejścia metodologiczne: dogmatyczno-prawne oraz formalno-dogmatyczne.

Słowa kluczowe: podmiotowość prawnomiędzynarodowa, podmiot prawa międzynarodowego, Suwerenny Zakon Kawalerów Maltańskich, eksterytorialność, osobowość prawnomiędzynarodowa, prawo międzynarodowe publiczne

Summary: Issues related to international subjectivity are among the most widely discussed in the doctrine. While the issue of subjectivity is resolved by legislators in the legal systems of individual states, there is no similar treaty norm in international law. Hence, the concept and understanding of subjectivity is an issue considered primarily by representatives of the doctrine of international law. Therefore, it was stated that the subject of international law should have legal capacity, in other words, the ability to have rights and obligations and the ability to perform legal acts - the possibility of direct contracting of rights and obligations, which is associated with the ability to appear in international relations. The doctrine assumes that the specific subject of international law is the Sovereign Order of the Knights of Malta. Thus, the author of the publication analyses the entity's subjectivity in terms of its ability to act in the field of international law, i.e. the ability to maintain diplomatic and consular relations, participate in international organisations, conclude agreements, submit claims and pursue them by referring to peaceful ways of settling international disputes, taking international responsibility, owning citizenship and territory.

Key words: subjectivity, order, sovereignty, international law, The Sovereign Military Order of Malta, exterritoriality, statehood

\section{Вступление}

Международное право - это особая правовая система, в которой конкретные субъекты сами создают правовые нормы, которым они адресованы. На международной арене нет центрального органа, ответственного за применение и обеспечение соблюдения международного права. Поэтому вопросы, касающиеся международно-правовой субъектности, вызывают много трудностей. Хотя проблема субъектности решается законодателями в правовых системах отдельных государств, в международном праве нет аналогичной договорной нормы ${ }^{1}$ В связи с этим можно сказать, что понятие и понимание субъектности является вопросом, рассматриваемым прежде всего представителями доктрины международного права².

Некоторые юридические лица, действующие в соответствии с церковным законодательством, имеют особый статус согласно международному праву. Некоторые рыцарские ордена могут быть включены в эту категорию. На

1 H. Thirlway, The Sources of International Law, Oxford 2019, s. 37.

2 K. Orzeszyna, Podmiotowość i suwerenność prawnomiędzynarodowa Zakonu Maltańskiego, Rocznik Nauk Prawych 2005, t. 15, nr 2, s. 172. 
протяжении веков некоторые из них имели свои государства. На сегодняшний день ни одно религиозное государство не сохранилось, однако Мальтийский орден ${ }^{3}$ сохраняет свой уникальный статус и рассматривается некоторыми представителями доктрины как особый субъект международного права ${ }^{4}$.

Целью данной статьи является определение правовой - субъектности Мальтийского ордена. Поэтому, чтобы определить, является ли орден субъектом международного права, необходимо проанализировать конкретные правовые концепции, связанные со статусом, правоспособностью ${ }^{5}$, свойствами, природой и объемом прав и обязанностей.

\section{1. Характеристика}

Суверенный Мальтийский орден является одним из орденов Римско-Католической Церкви, которая объединяет около 12000 рыцарей. Их ядро - аристократы из семей с более чем 200-летней дворянской традицией, что является одним из условий для высших достоинств в ордене. Остальные члены - самые влиятельные промышленники, финансисты, политики и интеллектуалы. Основной целью внешней деятельности ордена является оказание медицинской и благотворительной помощи более чем в 60 странах 6 . За эти годы орден сформировал собственную автономную правовую систему. Он имеет законодательные и исполнительные полномочия, центральные органы власти, а также судебную систему. Законодательная власть во всех вопросах, кроме вопросов, связанных с Конституцией, осуществляется Суверенным Советом и Великим

3 Полное название субъекта: Суверенный Иерусалимский Военно-монашеский Орден Госпитальеров им. Св. Иоанна, Родоса и Мальты (Sovrano Militare Ordine Ospedaliero di San Giovanni di Gerusalemme, detto di Rodi, detto di Malta). Его также иногда называют Орденом Родоса и Орденом Мальты.

4 K. Karski, Zakony rycerskie Kościoła katolickiego jako podmioty prawa międzynarodowego (studium historycznoprawne), Studia Iuridicia 2002, t. 40, s. 93.

5 Следует отметить, что в доктрине международного права принята гражданская концепция различия между правоспособностью и способностью к правовым деяниям. Соответственно, проводится различие между международной правоспособностью, т. е. способностью быть субъектом международных прав и обязанностей, а также способностью осуществлять международно-правовую деятельность, т. е. способностью приобретать права и брать на себя международные обязательства посредством собственных действий; L. Antonowicz, Podręcznik prawa międzynarodowego, Warszawa 2015, s. 21.

6 J. Sozański, Struktura organizacyjna Zakonu Maltańskiego na tle prawa międzynarodowego, Przegląd Stosunków Międzynarodowych 1990, nr 3-4, s. 78. 
Магистром. Глава отвечает за конституционные изменения. Исполнительная власть осуществляется Суверенным Советом под председательством Великого Магистра. Он состоит из десяти рыцарей Мальты, избираемых главойㄱ. Судьи, заседающие в судах первой и апелляционной инстанций, назначаются Великим Магистром и Суверенным Советом - должность судьи может выполнять только лицо, которое хорошо ознакомлено с законодательством Мальтийского ордена ${ }^{8}$. Представители органов власти выдают паспорта, документы, удостоверяющие личность, почтовые марки, присваивают титулы, права собственности и украшения. Кроме того, орден имеет свою собственную денежную систему, а его валюта называется scuto (множественное число лат. scuti). У ордена также есть флаг и гимн, официальный язык - итальянский ${ }^{9}$. Мальтийский орден был создан во время крестовых походов в госпитале св. Джона. Первоначально он был больничным братством, присматривающим за паломниками, которые пришли в Иерусалим. Позднее эта защита начала принимать форму защиты от нападений мусульман, чтобы в конечном итоге стать „вооруженной рукой Папы”. Первой ситуацией, когда Мальтийский орден мог получить целое государство и таким образом получить международную субъектность, является вопрос, касающийся Арагона. Тогдашний король Альфонсо I, которого звали Воин, решил, что рыцарские ордена должны наследовать королевство. Он отдал Королевство Арагон в наследство трём орденам, включая поздний Мальтийский орден ${ }^{10}$. После смерти правителя ордена требовали своё государство, но жители Арагона препятствовали правопреемству ${ }^{11}$.

Мальтийский орден управлял с 1309 по 1522 год островом Родос (в дополнение к этому также занимал окружающие острова: Кальки, Лимония, Сими, Пископия, Нисирос, Кос, Калимантан и Летро) ${ }^{12}$. Объединение этих территорий было одобрено Папой Римским и византийским императором. Такое положение дел создало новую правовую ситуацию на международной арене для ордена, поскольку, гарантировав суверенитет внутри иерархии

7 А.Е., Лестев, Морально-нравственные императивы рыцарей Суверенного Военного Мальтийского Ордена, Этнология и Культурная Антропология 2015, nr 4 (28), s. 409, doi: 10.7256/22221956.2015.4.15204.

8 T. Mirecki, Struktura zakonu, http://zakonmaltanski.pl/zpkm/struktura-zakonu [доступ: 10.09.2020 г.].

9 E. Buttigieg, Nobility, Faith and Masculinity: The Hospitaller Knights of Malta, c. $1580-$ c. 1700, London-New York 2011, s. 11.

10 В.А. Захаров, Суверенный Мальтийский орден - европейская реальность или исторический рудимент?, Россия XXI 2002, nr 4, s.118-150.

11 T. Lange, Szpitalnicy, Joannici, Kawalerowie Maltańscy, Warszawa 1999, s. 9-11.

12 K. Karski, Zakony rycerskie..., s. 93-106; А.Р. Андреев, В.А. Захаров, И.А. Настенко, История Мальтийского Ордена, Москва 1999, s. 18. 
Римско-Католической Церкви, он также получил территориальный суверенитет, что позволило ему создать свое собственное государство ${ }^{13}$. Созданной республикой управлял Великий Магистр, а религиозный глава имел совещательный голос. Орден потерял эту территорию в 1522 году после шести месяцев боев с турецкой армией. В соответствии с договором, заключенным с римским императором Карлом V Габсбургом, орден получил в то время Мальту и Гозо Сицилийского королевства. Монахи поселились на Мальте в 1530 году и управляли там до 1798 года, когда директорат издал указ о признании Мальтийского ордена врагом Французской Республики и послал армию Наполеона занять остров ${ }^{14}$. Хотя орден был вынужден покинуть Мальту, он сохранял свою юридическую субъектность и обменивался дипломатическими миссиями с европейскими странами. В 1834 году он переехал в Рим, где действовал как благотворительная и гуманитарная организация ${ }^{15}$. Переданный одним из рыцарей Мальтийского ордена дворец на улице Кондотти 68, далее известный как Палаццо ди Мальта, стал местом религиозного управления. По сей день, вместе с виллой на Авентинском холме, дворец является главным местонахождением Мальтийского ордена, образуя в то же время территорию, которая является важным аргументом в юридическом обосновании субъектности. Кроме того, орден получил форт Сан-Анджело в 1999 году от Республики Мальта ${ }^{16}$. Территория также включает в себя многочисленные посольства. Однако следует подчеркнуть, что недвижимость функционирует на экстерриториальной основе ${ }^{17}$. В настоящее время Мальтийский орден занимается обширной благотворительной и гуманитарной деятельностью. Он в основном работает в сфере оказания медицинской помощи, управляет многочисленными больницами, домами для инвалидов и престарелых, а также хосписами. Кроме того, его представители появляются в районах, затронутых вооруженными конфликтами и в местах стихийных бедствий. Дополнительно, они участвуют в многочисленных кампаниях, пропагандирующих профилактику и борьбу с такими заболеваниями, как проказа и СПИД ${ }^{18}$.

13 В. Захаров, Мальтийский орден как европейское государство, Современная Европа 2002, $\mathrm{nr}$ 2, s. 74.

14 Р. Де Верто, История мальтийских рыцарей, Москва 2014, s. 512.

15 J. Baranowski, M. Libicki, A. Rottermund, M. Starnowska, Zakon Maltański w Polsce, Warszawa 2000, s. 5.

16 T. Lange, Szpitalnicy..., s. 43-44.

17 K. Karski, Osoba prawna prawa wewnętrznego jako podmiot prawa międzynarodowego, Warszawa 2009, s. 281.

18 B. Kuźniak, Zakon Kawalerów Maltańskich - suweren bez ziemi?, w: Państwo i terytorium w prawie międzynarodowym, red. J. Menkes, E. Cała-Wacinkiewicz, Warszawa 2015, s. 370. 


\section{2. Юридическая субъектность}

Вопросы, связанные с субъектностью международного права, относятся к числу наиболее часто обсуждаемых в науке. В то время как во внутригосударственном праве законодатель однозначно решает проблему субъективности, указывая, кто и как приобретает субъектность, в международном праве подобная конвенционная норма отсутствует. Следовательно, концепция и понимание субъектности - это вопрос, рассматриваемый в первую очередь доктриной ${ }^{19}$.

Субъектами международного публичного права являются те субъекты, которые действуют в отношениях такого характера. Их поведение напрямую регулируется международным правом, нормы которого определяют их права и обязанности. Наука международного права приняла гражданскую концепцию разницы между правоспособностью и дееспособностью. Соответственно, проводится различие между международной правоспособностью, то есть способностью быть субъектом международных прав и обязательств, и способностью совершать международно-правовые действия, то есть способностью приобретать права и брать на себя международные обязательства своими собственными действиями ${ }^{20}$. Субъектами публичного международного права являются те, кто действует в таких отношениях. Их поведение регулируется непосредственно международным правом, из норм которого вытекают их права и обязанности ${ }^{21}$. Тем не менее, доктрина имеет много различных и часто противоречивых теорий о международно-правовой субъектности ${ }^{22}$. Чаще всего предполагается, что субъекты получают свои права и обязанности непосредственно из международного права. Следует согласиться с предложенным Ярославом Созаньским определением, что „субъект международного права - это тот, кто имеет независимую позицию на рынке, особенно способность создавать и применять нормы этого закона" ${ }^{23}$. Основным и самым важным субъектом является государство, которое является

19 K. Orzeszyna, Podmiotowość..., s. 172; tenże, Struktura organizacyjna Zakonu Maltańskiego na tle prawa międzynarodowego, Przegląd Stosunków Międzynarodowych 1990, nr 3-4 (145-146), s. 78.

20 J. Gilas, Prawo międzynarodowe, Toruń 1999, s. 114; Г. Игнатенко, О. Тиунов, Международное право, Москва 2010, s. 67; M. Shaw, Prawo międzynarodowe, Warszawa 2006, s. 135.

21 P. Bogacki, Zagadnienie podmiotowości prawnej w stosunkach międzynarodowych, Roczniki Nauk Prawnych 1997, t. 7, s. 213.

22 W. Góralczyk, S. Sawicki, Prawo międzynarodowe publiczne w zarysie, Warszawa 2017, s. 129.

23 J. Sozański, Prawo traktatów: zarys współczesny, Warszawa 2008, s. 35. 
единственным, суверенным, полным и оригинальным ${ }^{24}$. Следовательно, другие субъекты международного права должны рассматриваться как несуверенные, неполные и все же производные. Это выражается в характере их субъектности, которая была создана или признана государствами. Кроме того, они обладают субъектностью в той мере, в какой это было дано им государствами ${ }^{25}$. Международный Суд в своем консультативном заключении о компенсации ущерба, понесенного на службе ООН в 1949 году, указал, что

субъекты права в правовой системе не обязательно идентичны с точки зрения их прав; их природа зависит от потребностей сообщества. На развитие международного права на протяжении всей его истории влияли требования международной жизни, и постепенный рост коллективных действий государств уже привел к появлению примеров деятельности, осуществляемой на международном уровне определенными субъектами, которые не являются государствами ${ }^{26}$.

На основании консультативного заключения можно сделать вывод, что на международной арене не существует единого единого списка организаций. С одной стороны, существуют отдельные государства, а с другой - другие субъекты международного права, к которым они также относятся по-разному ${ }^{27}$. Таким образом, организации, действующие в международной среде, обладают разнообразным характером и сферой компетенций ${ }^{28}$.

Согласно доктрине, практика государств решает, кто является субъектом международного права. Также признано, что свидетельство субъектности это наиболее важные ее проявления. Наиболее распространенными среди них являются: поддержание дипломатических отношений, заключение международных договоров, участие в межправительственных конгрессах и членство в международных организациях. Первые два элемента были определены

24 Следует отметить, что в доктрине также существует позиция, согласно которой государство является единственным (исключительным) субъектом международного права. В своих соображениях теоретики ссылаются на пункт 1 статьи 34 Статута Международного суда ООН, в котором говорится, что „только государства имеют право выступать в качестве участников Суда”. Как следствие, теоретики приходят к выводу, что только государство является субъектом международного права; A. Klafkowski, Prawo międzynarodowe publiczne, Warszawa 1981, S. 134.

25 R. Bierzanek, J. Symonides, Prawo międzynarodowe publiczne, Warszawa 2005, s. 118.

26 M. Szwejkowska, K. Milkowski, Suwerenny Zakon Kawalerów Maltańskich jako podmiot prawa międzynarodowego, Studia Prawnoustrojowe 2018, t. 38, s. 60.

27 N. Cox, The continuing question of sovereignty and the Sovereign Military Order of Jerusalem of Rhodes and of Malta, Australian International Law Journal 2006, nr 13 (1), s. 212.

28 W. Czapliński, A. Wyrozumska, Prawo międzynarodowe publiczne. Zagadnienia systemowe, Warszawa 2014, s. $167-168$. 
как ius legationis и ius tractatuum. Мальтийский орден пользуется своими правами в полной автономии. Он имеет активное и пассивное право посольства и право заключать международные соглашения ${ }^{29}$. Большинство заключенных им контрактов касалось дипломатических отношений и гуманитарной деятельности. Обычно Ордену предоставлялся статус наблюдателя при участии в межправительственных съездах.

Субъектность Мальтийского ордена может вызвать сомнения в связи с тем, что в традиционном смысле не имеет территории, постоянного населения и суверенитета. Следует помнить, что народ составляют монахи, и Магистр 30 ордена, который обладает властью. В настоящее время в состав Мальтийского ордена входят около 12000 человек, которые делятся на разные категории. Орден разделен на классы: 1. Профессиональные рыцари, 2. Рыцари и дамы в послушании, 3. Члены ордена, которые не являются профессиональными рыцарями или рыцарями в повиновении. Специфика субъектности Ордена также выражается в том факте, что он сформирован двумя категориями людей, а именно: Иоаннитами, в буквальном смысле, то есть безбрачными госпитальерами, принявшими религиозные обеты, что означает, что их союз как с Великим Магистром, так и со Святым Престолом более крепкий, и со стороны других членов сообщества Иоаннитов, которые являются мирянами и не вписываются по крайней мере в стереотип типичного религиозного деятеля ${ }^{31}$. Кроме того, отдельные классы делятся на подклассы. Подавляющее большинство рыцарей Мальтийского ордена каждый день пребывает за территорией ордена ${ }^{32}$. С другой стороны, территория состоит из недвижимости, предоставленной ордену на основании экстерриториальности. Хотя Мальтийский орден имеет территории с экстерриториальным статусом, он не осуществляет территориальный суверенитет над ними. Согласно концепции Георга Еллинка, государственная территория - это

территория, на которой было создано государственное объединение. В этой области государственная власть осуществляет свои полномочия. Для существования государства территория должна быть неразрывно связана с государственной

29 J. Sozański, Wspótczesne prawo traktatów, Warszawa-Poznań 2003, s. 26.

30 Суверенитет ордена осуществляется Принцем и Великим Магистром как Верховным Наставником, а также советом, поддерживающим его. Жизнь ордена регулируется Конституционной хартией и Кодексом, которые были реформированы в 1997 году.

31 A. Ławniczak, Oryginalne rozwiązania systemów rzadów na przykładzie Zakonu Maltańskiego, Przegląd Prawa Konstytucyjnego 2014, nr 3, s. 81; M. Dygo, Zakony rycerskie, w: Rozkwit średniowiecznej Europy, red. H. Samsonowicz, Warszawa 2011, s. 392-395.

32 A. Cieślak, Obowiązujacy podział członków Zakonu Kawalerów Maltańskich, www.ambasada.zakon maltanski.pl/wladze.htm [доступ: 10.09.2020 г.]. 
властью. Из-за этой неразделимости территории она также связана с суверенитетом ${ }^{33}$.

Учитывая выше приведенное определение, можно сделать вывод, что орден не имеет территории в традиционном смысле. Следует подчеркнуть, что эта концепция является доминирующей, но доктрина также включает теории, которые допускают существование нетерриториального государства ${ }^{34}$. Такой подход предполагает необходимость отступления от идентичности государства и территории в пользу идентичности государства и закона ${ }^{35}$. Мальтийский орден является институционализированной единицей с многовековой традицией, которая никогда не теряла своего характера в истории, потому что в самые трудные времена „суверенитет конгрегации был признан несколькими католическими странами, включая Австрию, которая никогда не отказывалась от своего признания" ${ }^{36}$. Существует также широкое международное признание того, что орден рассматривается как субъект международного права. Официальным его признали около ста стран, некоторые из которых установили с Мальтийским орденом дипломатические отношения.

\section{3. Отношения с Апостольской Столицей}

Поскольку приказы возникают по решению, принятому Святейшим Престолом, и подчиняются ему через Конгрегация доктрины веры, положение Папы является обязательным для Мальтийского ордена. Конституционная хартия ордена, а также кодекс, прилагаемый к ней, указывают на многие права, которыми наделен Святой Престол в отношении ордена ${ }^{37}$. По мнению Г. Рысяка: „Суверенитет в международном праве означает независимость государства от любых внешних факторов и его независимость в регулировании внутренних дел" 38 . Эта независимость связана с внешним фактором, например,

33 G. Jellinek, Allgemeine Staatslehre, Bad Homburg-Berlin-Zürich 1966, s. 395.

34 Z. Rykiel, Podstawy geografii politycznej, Warszawa 2006, s. 93; H. Kelsen, Principles of International Law, New York 1952, s. 53.

35 J. Tyranowski, Sukcesja państw a traktaty w sprawie granic, Poznań 1979, s. 76.

36 A. Ławniczak, Oryginalne..., s. 75; D. Seward, Mnisi wojny. Krótka historia zakonów rycerskich, Poznań 2005, s. 263.

37 B. Kuźniak, Zakon..., s. 369; R. Kwiecień, Suwerenność państwa - geneza i rozwój idei w prawie międzynarodowym, Studia Prawnicze 2002, nr 3, s. 5.

38 G. Rysiak, Suwerenność, w: Encyklopedia prawa międzynarodowego i stosunków międzynarodowych, kom. red. A. Klafkowski, Warszawa 1976, s. 378. 
с другой страной или международной организацией. Независимость в регулировании внутренних дел - это право регулировать все отношения внутри государства, на основании которых государство наделено территориальной и личной властью. Следствием этого является презумпция исключительной компетенции государства регулировать все свои отношения и соответствующая презумпция исключительной ответственности государства за все, что происходило в территориальных, личных, материальных и юридических рамках, охватываемых его суверенитетом. Хотя суверенитет не обусловливает, субъектность, он играет важную роль с точки зрения ее приобретения и охвата. Суверенные субъекты, такие как государства, имеют первостепенный характер, и их правовые действия полны. Напротив, несуверенные субъекты, такие как международные организации, имеют производный и ограниченный характер. Их субъектность - это результат предоставления или признания. В ситуации, когда участники международной юридической торговли не соответствуют этим двум типам субъектности, они считаются другими субъектами. Эта категория очень разнообразна. В ее состав входит Мальтийский орден. Сегодня хорошо известно о существовании субъектов международного права, помимо государств. Косвенно это подтверждается ст. 3 Венской конвенции о праве международных договоров от 23 мая 1969 года ${ }^{39}$. Таким образом, решающим фактором является внутренняя способность данного организма занимать субъектную позицию. Признание субъектности Мальтийского ордена государствами в форме соглашений и дипломатических отношений является практической проверкой вышеуказанной теоретической структуры. Поэтому возникают сомнения относительно субъектности рассматриваемой единицы ${ }^{40}$.

В классическом международном праве предполагалось, что суверенитет является определяющим фактором для субъектности. Понятие суверенитета обычно означает независимость авторитета данного субъекта от любого другого авторитета. С точки зрения доктрины международного права, независимо от внутренних норм личности, суверенитет является элементом власти, который олицетворяет и представляет субъект в международных отношениях. Он является высшей властью и не подчиняется какой-либо

39 M. Perkowski, Podmiotowość prawa międzynarodowego współczesnego uniwersalizmu w złożonym modelu klasyfikacyjnym, Białystok 2008, s. 269; B. Wierzbicki, Prawo międzynarodowe, Białystok 2008, s. 138-140.

40 М.Р. Гилязетдинов, Проблемы в понимании суверенитета и международно-правового статуса Суверенного Мальтийского ордена, Вестник Пермского института ФСИН России 2017, nr 2(25), s. 5-6. 
другой внешней власти, а также имеет первичную природу, что проявляется в том, что он не получает своих полномочий от какой-либо другой власти ${ }^{41}$. В этих соображениях следует обратить внимание на мнение Ильи Цацки: „Третья статья первого раздела конституции является для нас наиболее интересной, так как в ней прописывается суверенность Мальтийского ордена: «Орден является субъектом международного права и выполняет суверенные функции»" 42 . Чтобы определить нынешний статус Мальтийского ордена рыцарей, чрезвычайно важно определить характер его отношений со Святым Престолом. Он является - очевидно - одним из орденов Католической Церкви ${ }^{43}$. Следует подчеркнуть, что в настоящее время Мальтийский орден не обладает суверенитетом в том смысле, в каком он существует у государств, но в своей международной деятельности он независим от других субъектов международного права, а его суверенитет имеет определенные ограничения, вытекающие из фактического подчинения Папе Римскому, а также из целей и задач, которые Орден должен выполнять в международных отношениях ${ }^{44}$.

Однако в 1953 году специальный кардинальный суд, назначенный Папой Пием XII, постановил, что Мальтийский орден обладает субъектностью ${ }^{45}$. Представители трибунала определили его как „функциональный”, связанный с международной деятельностью, а не „территориальный” (он ориентирован на обеспечение целей и задач ордена в современном мире $)^{46}$. Таким образом, кажется законным, что специфическая субъектность Мальтийского ордена, описываемая как „функциональная”, не может выходить за рамки его признанных компетенций ${ }^{47}$. Орден Мальтийских рыцарей, несмотря на усилия по достижению такого статуса, не является, однако, оригинальным, то есть суверенным субъектом международного права. Его монашеский характер мешает ему иметь реальную власть. Это означает, прежде всего, независимость от какой-либо внешней власти. Однако в случае Римско-Католической Церкви это абсолютно невозможно. Даже самая широкая автономия ордена

41 C. D'Olivier Farran, The Sovereign Order of Malta in International Law, International \& Comparative Law Quarterly 1954, t. 3, nr 2, s. 217-234.

42 И.П. Цацка, О суверенитете..., s. 78.

43 K. Karski, Zakony rycerskie..., s. 101.

44 L. Sosnowski, Zakon Maltański jako podmiot prawa międzynarodowego, Przegląd Stosunków Międzynarodowych 1981, nr 2-3, s. 241-245; K. Karski, Zakony rycerskie..., s. 104.

45 А.Р. Андреев, В.А. Захаров, И.А. Настенко, История..., s. 94-95.

46 И.П. Цацка, О Суверенитете Духовно-Рьцарского Мальтийского Ордена, Вестник ОГУ 2013, nr 7 (156), s. 79; W. Jakubowski, Ustrój Stolicy Apostolskiej i Zakonu Maltańskiego, w: Społeczeństwo i polityka. Podstawy nauk politycznych, red. K. Wojtaszczyk, W. Jakubowski, Warszawa 2007, s. 655.

47 K. Orzeszyna, Podmiotowość..., s. 182. 
не лишает его суверенитета Папы. Все права Ордена, как и сам Орден, могут быть отменены решением Святого Престола. Даже сегодня, признавая очень широкий объем полномочий Ордена, Святой Престол оставил себе полномочия, которые никоим образом не вписываются в образ отношений между двумя суверенными субъектами международного права. И это не только полномочия религиозного характера. Глава Святейшего Престола каждый раз утверждает изменения, вносимые органами Ордена в его Конституционную хартию, и каждый раз утверждает выбор Великого Магистра, то есть главы Ордена - главы его исполнительной власти и высшего законодательного органа $^{48}$. Особого внимания заслуживает тот факт, что в декабре 2016 года начался кризис лидерства, инициированный Великим Магистром Робертом Мэтью Фестингом, который отстранил Альбрехта фон Бозелагера от должности Великого Канцлера. В январе 2017 года вмешался Папа Франциск, который приказал восстановить фон Бозелагера и потребовал, чтобы Фестинг ушел с поста Великого Магистра. Великий Магистр Роберт Мэтью Фестинг наконец подал в отставку. Папа Франциск также назначил архиепископа Джованни Беччу своим личным представителем в Ордене, сняв с этой должности кардинала-покровителя Ордена Раймонда Берка до избрания нового Великого Магистра Джакомо Далла Торре дель Темпио ди Сангуинетто 2 мая 2018 года. Более того, Папа продлил свой мандат Джованни Беччу на неопределенный срок. Эффективное принятие контроля над орденом Папой было воспринято некоторыми как разрыв с традициями с независимостью ордена ${ }^{49}$.

Очевидно, что субъект не является суверенным субъектом, если его конституция должна быть принята главой другого субъекта, и такое же - внешнее - одобрение требуется при выборе главы этого субъекта. Более того, Кассационный суд Ватикана является апелляционным судом по решениям

48 K. Karski, Zakony rycerskie..., s. 103.

49 J. McElwee, New Knights of Malta leader genuflects before Francis in Vatican meeting, National Catholic Reporter, https://www.ncronline.org/blogs/ncr-today/new-knights-malta-leader-genuflectsfrancis-vatican-meeting [доступ: 10.10.2020 г.]; Holy See Press Office, Letter of the Holy Father to the Special Delegate at the Sovereign Military Hospitaller Order of Saint John of Jerusalem, of Rhodes and of Malta (S.M.O.M.), 04.05.2018, https://press.vatican.va/content/salastampa/en/bollettino/ pubblico/2018/05/04/180504b.html [доступ: 10.10.2020 г.]; H. Brockhaus, Pope Francis extends mandate of special delegate to Knights of Malta, Catholic News Agency, https://www.catholicnewsagency. com/news/pope-francis-extends-mandate-of-special-delegate-to-knights-of-malta-24261[доступ: 10.10.2020 г.]; Order of Malta, The Chapter General of the Sovereign Order of Malta has been held in Rome, https:/www.orderofmalta.int/2019/05/02/chapter-general-sovereign-order-of-malta-has-beenheld-rome/ [доступ: 10.10.2020 г.]; E. Arocho, Ancient order, modern times: Order of Malta focuses on renewal, https://www.ncronline.org/news/vatican/ancient-order-modern-times-order-malta-focusesrenewal [доступ: 10.10.2020 г.]. 
трибуналов Ордена, который действует как Верховный суд Суверенного ордена Мальтийских рыцарей.

В польской литературе существуют различные взгляды на вопросы, связанные с субъектностью Мальтийского ордена. Юлиан Маковский - упоминая его в главе, посвященной субъектам международного права, - заявляет, что этот Орден „ [...] имеет лишь некоторые признаки субъекта международного права”. В результате он включил его в число „ограниченных субъектов” международного права ${ }^{50}$. Лех Антонович представляет мнение, что в то время, когда орден имел свою территорию, он рассматривался как субъект международного права, тогда как в настоящее время можно предположить, что он использует только определенные признаки субъектности только по отношению к странам, которые признают его ${ }^{51}$. Яцек Барчик и Томаш Срогош считают, что Мальтийский орден обладает правосубъектностью, которая не основана на территориальном суверенитете. Это своеобразная сущность, которая не отождествляется с государством, но имеет право на так называемый функциональный суверенитет, проявляющийся в ограниченном спектре деятельности на международной арене (компетенции были ограничены деятельностью, связанной с гуманитарной помощью) ${ }^{52}$. Войцех Гуральчик и Стефан Савицки квалифицировали Мальтийский орден в категорию „субъектов международного права, кроме государств”. Эти авторы указывают на то, что орден широко рассматривается как субъект, обладающий международным правом, что проявляется в том, что он признан многими странами и установил дипломатические отношения со многими из этих стран. Кроме того, он поддерживает свои дипломатические миссии в международных организациях и заключил многочисленные международные соглашения со многими субъектами международного права в последние годы ${ }^{53}$. Мальтийский орден как субъект также рассматривает Ян Бялоцеркевич, который указывает, что Мальтийский орден имеет право на такие атрибуты субъектности, как активное и пассивное право на легацию и ius tractatuum в сфере проводимой деятельности ${ }^{54}$. В свою очередь, Адам Лазовский и Анна Завидзка-Лойек подчеркивают традиционный характер субъектности ордена. Они указывают, что орден не принимает активного участия в современной международной торговле, и тем не менее он пользуется правом легации и заключает

50 J. Makowski, Podręcznik prawa międzynarodowego, Warszawa 1948, s. 96.

51 L. Antonowicz, Podręcznik..., s. 83-85.

52 J. Barcik, T. Srogosz, Prawo międzynarodowe publiczne, Warszawa 2007, s. 156.

53 W. Górlaczyk, S. Sawicki, Prawo..., s. 139.

54 J. Białocerkiewicz, Prawo międzynarodowe publiczne. Zarys wykładu, Olsztyn 2007, s. 140-141. 
международные соглашения, хотя и в ограниченной степени ${ }^{55}$. Как метко заявляет Януш Гилас: „Мальтийский орден является субъектом международного права, субъектность которого исторически сложилась как древнейший территориальный суверен”56. Интересно, что статус Ордена также является предметом российской доктрины. Юрий Колосов указывает на то, что Мальтийский орден сохраняет элементы субъектности международного права. Он признает это как конкретное следствие многовекового непрерывного существования Ордена как суверенного и независимого государственного образования, а также как результат признания современной роли Ордена в работе международной благотворительности ${ }^{57}$.

Международно-правовая субъектность характеризуется различными представителями доктрины. Часто указываются атрибуты данной единицы, которые должны определять ее как субъект международного права ${ }^{58}$. Однако в контексте Мальтийского ордена особое внимание следует уделить меткому мнению Кароля Карского о том, что орден является второстепенным субъектом международного права, поскольку его международно-правовой статус зависит от признания первичными образованиями ${ }^{59}$. Если нет субъективного desuetudo, нынешнее состояние сохранится ${ }^{60}$.

\section{4. Международный аспект}

Согласно доктрине, государственная практика решает, кто является субъектом международного права. Признано, что доказательства субъектности являются ее наиболее значительными проявлениями. Таким образом, субъекты международного права имеют определенные атрибуты. К ним относятся способность заключать международные соглашения (lat. ius tractatuum / ius contrahendi), право на легацию (ius legationis), право на членство в международных организациях, возможность предъявлять требования или нести

55 A. Łazowski, A. Zawidzka-Łojek, Prawo międzynarodowe publiczne, Warszawa 2011, s. 85-86.

56 J. Gilas, Prawo..., s. 119.

57 Ю.М. Колосов, Э.С. Кривчикова, Д.В. Иванов, Международное право, Москва 2000, s. 85-86.

58 В. Kuźniak, Zakon..., s. 373; В.А. Захаров, Мальтийский орден и его место в системе европейских государств, Вопросы истории 2006, nr 8, s. 22-38.

59 K. Karski, The International Legal Status of the Sovereign Military Hospitaller Order of St. John of Jerusalem of Rhodes and of Malta, International Community Law Review 2012, t. 14, nr 1, s. 19-32.

60 A. Ławniczak, Oryginalne..., s. 82. 
ответственность перед международным правом (ius standi) ${ }^{61}$. Однако следует отметить, что список атрибутов, представленных разными авторами, разнообразен. Атрибутом субъектности Мальтийского ордена является ius tractatuum, то есть возможность заключения юридических обязательств с субъектами международного права. Именно эта способность дает право инициировать, создавать, заключать и применять договоры в качестве актов международного права. Однако следует отметить, что характер и сфера действия ius tractatuum субъектов, не являющихся государствами и международными организациями, будут зависеть от характера и атрибутов конкретного субъекта. Исходя из этого, договорная способность Мальтийского ордена не очень эффективна, поскольку она ограничена его публичными целями, что тесно связана со статусом этой организации ${ }^{62}$. Большинство международных соглашений, участником которых является Мальтийский орден, относится к медицинской, благотворительной и гуманитарной деятельности. Таким образом, двусторонние соглашения Мальтийского ордена с государствами и организациями ограничиваются управлением больницами, оказанием помощи раненым и больным в вооруженных конфликтах, а также почтовыми конвенциями ${ }^{63}$. Как правильно отмечает Илья Цацка: „орден оставляет за собой право ведения международной деятельности, а также участия в международной политике. Орден может заключать международные соглашения. Это роднит его с международными организациями, а также с государствами"64.

Стоит отметить, что 18 апреля 1991 года министр связи Республики Польша заключил соглашение о сотрудничестве с Главным почтовым отделением ордена в области оказания почтовых услуг. В результате этого сотрудничества польская почта в 1992 году выпустила почтовую марку стоимостью 3000 злотых с гербом Мальтийского ордена ${ }^{65}$.

Мальтийский орден также осуществляет ius legationis, как в активной, так и пассивной форме, состоящую в создании и отправке дипломатических и консульских представительств, целью которых является выполнение задач, связанных с осуществлением дипломатических и консульских отношений ${ }^{66}$.

61 M. Perkowski, Podmiotowość..., s. 194-197.

62 J. Sozański, Prawo..., s. 81-84.

63 K. Orzeszyna, Podmiotowość..., s. 179.

64 И.П. Цацка, О суверенитете..., s. 78.

65 J. Baranowski, M. Libicki, A. Rottermund, M. Starnowska, Zakon..., s. 189-190.

66 J. Sozański, Podmiotowość prawnomiędzynarodowa suwerennego Zakonu Kawalerów Maltańskich, Sprawy Międzynarodowe 1990, nr 2, s. 126; E. Karska, Zakon Maltański jako szczególny podmiot prawa legacji, w: 50 lat Konwencji wiedeńskiej - aktualna kondycja uregulowań dotyczących stosunków dyplomatycznych, red. Z. Galicki, T. Kamiński, K. Myszona-Kostrzewa, Warszawa 2012, s. 213-252. 
Следует отметить, что право отправлять представителей является исключительной компетенцией отправляющего государства, тогда как право принимать или отклонять допуск принадлежит принимающему государству ${ }^{67}$. Это право было подтверждено буллой Папы Климента V от 1466 года, что означает, что оно принадлежит правам, приобретенным на протяжении всей истории ${ }^{68}$. Мальтийский орден поддерживает дипломатические отношения со 105 странами и имеет свои представительства в мультилатеральных организациях. Дипломатические отношения с Польшей были установлены 9 июля 1990 года. Вскоре после этого Мальтийский орден аккредитовал своего посла в Польше ${ }^{69}$. То, что международное сообщество признает орден в качестве субъекта международного права, также подтверждается тем фактом, что с 1994 года ему был предоставлен статус постоянного наблюдателя в Организации Объединенных Наций. Он также работает в специализированных структурах ООН (таких как ЮНЕСКО, ФАО, ПАМ, ВОЗ, УВКБ ООН, УВКПЧ) и Европейской комиссии. Мальтийский орден также имеет делегации в различных других международных организациях, например, в Международном комитете Красного Креста.

В связи с вышеизложенным следует отметить, что Мальтийский орден осуществляет свои права полностью автономно. Он имеет активные и пассивные права на легализацию и право заключать международные соглашения. Однако нет никаких сомнений в том, что большинство его соглашений касались дипломатических отношений и гуманитарной деятельности. Что касается участия в межправительственных конференциях, Мальтийскому ордену обычно предоставляется статус наблюдателя ${ }^{70}$.

\section{Заключение}

Таким образом, следует отметить, что Мальтийский орден является особым субъектом международного права. С точки зрения доктрины, нет сомнений, что он обладает субъектностью, которая позволяет ему действовать в сфере международных отношений, но в ограниченной степени. Однако стоит под-

67 J. Sutor, Prawo dyplomatyczne i konsularne, Warszawa 2003, s. 84.

68 P. Łaski, Status prawnomiędzynarodowy Zakonu Maltańskiego, Annales Universitatis Mariae CurieSkłodowska Lublin-Polonia 1995, t. 42, nr 4, sec. G, s. 45-46.

69 J. Baranowski, M. Libicki, A. Rottermund, M. Starnowska, Zakon..., s. 189.

70 J. Sozański, Struktura organizacyjna Zakonu Maltańskiego..., s. 131. 
черкнуть, что это уникальная единица - несмотря на то, что она потеряла свое состояние более двух веков назад, она сохранила определенные права по сей день. Следует сделать вывод, что Мальтийский орден имеет особый, сформированный на протяжении всей истории характер, что делает его sui generis субъектом международного права. Это подтверждается тем фактом, что он заключает соглашения и поддерживает международные отношения со многими странами, включая Польшу, что каким-то образом также подтверждает его субъектность в международном праве. Практика государств, которые рассматривают Мальтийский орден как эквивалентный субъект международного права, хотя и с ограниченной областью компетенций, оказалась решающей. Следовательно, если нет субъективного desuetudo, нынешнее состояние, вероятно, сохранится.

\section{Bibliografia}

Antonowicz L., Podręcznik prawa międzynarodowego, Warszawa 2015.

Arocho, Ancient order, modern times: Order of Malta focuses on renewal, https://www .ncronline.org/news/vatican/ancient-order-modern-times-order-malta-focuses-renewal [доступ: 10.10.2020 г.].

Baranowski J., Libicki M., Rottermund A., Starnowska M., Zakon Maltański w Polsce, Warszawa 2000.

Barcik J., Srogosz T., Prawo międzynarodowe publiczne, Warszawa 2007.

Białocerkiewicz J., Prawo międzynarodowe publiczne. Zarys wykładu, Olsztyn 2007.

Bierzanek R., Symonides J., Prawo międzynarodowe publiczne, Warszawa 2005.

Bogacki P., Zagadnienie podmiotowości prawnej w stosunkach międzynarodowych, Roczniki Nauk Prawnych 1997, t. 7.

Brockhaus H., Pope Francis extends mandate of special delegate to Knights of Malta, Catholic News Agency, https://www.catholicnewsagency.com/news/pope-francis-extends -mandate-of-special-delegate-to-knights-of-malta-24261 [доступ: 10.09.2020 г.].

Buttigieg E., Nobility, Faith and Masculinity: The Hospitaller Knights of Malta, c. 1580-c. 1700, London-New York 2011.

Cieślak A., Obowiązujący podział członków Zakonu Kawalerów Maltańskich, www.ambasada .zakonmaltanski.pl/wladze.htm [доступ: 10.09.2020 г.].

Cox N., The continuing question of sovereignty and the Sovereign Military Order of Jerusalem of Rhodes and of Malta, Australian International Law Journal 2006, nr 13 (1).

Czapliński W., Wyrozumska A., Prawo międzynarodowe publiczne. Zagadnienia systemowe, Warszawa 2014.

D'Olivier Farran C., The Sovereign Order of Malta in International Law, International \& Comparative Law Quarterly 1954, t. 3, nr 2. 
Dygo M, Zakony rycerskie, w: Rozkwit średniowiecznej Europy, red. H. Samsonowicz, Warszawa 2011.

Gilas J., Prawo międzynarodowe, Toruń 1999.

Góralczyk W., Sawicki S., Prawo międzynarodowe publiczne w zarysie, Warszawa 2017.

Jakubowski W., Ustrój Stolicy Apostolskiej i Zakonu Maltańskiego, w: Społeczeństwo i polityka. Podstawy nauk politycznych, red. K. Wojtaszczyk, W. Jakubowski, Warszawa 2007.

Jellinek G., Allgemeine Staatslehre, Bad Homburg-Berlin-Zürich 1966.

Karska E., Zakon Maltański jako szczególny podmiot prawa legacji, w: 50 lat Konwencji wiedeńskiej - aktualna kondycja uregulowań dotyczących stosunków dyplomatycznych, red. Z. Galicki, T. Kamiński, K. Myszona-Kostrzewa, Warszawa 2012

Karski K., Zakony rycerskie Kościoła katolickiego jako podmioty prawa międzynarodowego (studium historycznoprawne), Studia Iuridicia 2002, t. 40.

Karski K., Osoba prawna prawa wewnętrznego jako podmiot prawa międzynarodowego, Warszawa 2009.

Karski K., The International Legal Status of the Sovereign Military Hospitaller Order of St. John of Jerusalem of Rhodes and of Malta, International Community Law Review 2012, t. 14, nr 1.

Kelsen H., Principles of International Law, New York 1952.

Klafkowski A., Prawo międzynarodowe publiczne, Warszawa 1981.

Kuźniak B., Zakon Kawalerów Maltańskich - suweren bez ziemi?, w: Państwo i terytorium w prawie międzynarodowym, red. J. Menkes, E. Cała-Wacinkiewicz, Warszawa 2015.

Kwiecień R., Suwerenność państwa - geneza i rozwój idei w prawie międzynarodowym, Studia Prawnicze 2002, nr 3.

Lange T., Szpitalnicy, Joannici, Kawalerowie Maltańscy, Warszawa 1999.

Łaski P., Status prawnomiędzynarodowy Zakonu Maltańskiego, Annales Universitatis Mariae Curie-Skłodowska Lublin-Polonia 1995, t. 42, nr 4, sec. G.

Ławniczak A., Oryginalne rozwiązania systemów rządów na przykładzie Zakonu Maltańskiego, Przegląd Prawa Konstytucyjnego, nr 3.

Łazowski A., Zawidzka-Łojek A., Prawo międzynarodowe publiczne, Warszawa 2011.

Makowski J., Podręcznik prawa międzynarodowego, Warszawa 1948.

McElwee J., New Knights of Malta leader genuflects before Francis in Vatican meeting, National Catholic Reporter, https://www.ncronline.org/blogs/ncr-today/new-knights-malta-leader-genuflects-francis-vatican-meeting [доступ: 10.09.2020 г.]

Mirecki T., Struktura zakonu, http://zakonmaltanski.pl/zpkm/struktura-zakonu [доступ: 10.09.2020 г.].

Orzeszyna K., Struktura organizacyjna Zakonu Maltańskiego na tle prawa międzynarodowego, Przegląd Stosunków Międzynarodowych 1990, nr 3-4 (145-146).

Orzeszyna K., Podmiotowość i suwerenność prawnomiędzynarodowa Zakonu Maltańskiego, Rocznik Nauk Prawych 2005, t. 15, nr 2.

Perkowski M., Podmiotowość prawa międzynarodowego współczesnego uniwersalizmu w złożonym modelu klasyfikacyjnym, Białystok 2008.

Rykiel Z., Podstawy geografii politycznej, Warszawa 2006.

Rysiak G., Suwerenność, w: Encyklopedia prawa międzynarodowego i stosunków międzynarodowych, kom. red. A. Klafkowski, Warszawa 1976.

Seward D., Mnisi wojny. Krótka historia zakonów rycerskich, Poznań 2005. 
Shaw M., Prawo międzynarodowe, Warszawa 2006.

Sosnowski L., Zakon Maltański jako podmiot prawa międzynarodowego, Przegląd Stosunków Międzynarodowych 1981, nr 2-3.

Sozański J., Podmiotowość prawnomiędzynarodowa suwerennego Zakonu Kawalerów Maltańskich, Sprawy Międzynarodowe 1990, nr 2.

Sozański J., Struktura organizacyjna Zakonu Maltańskiego na tle prawa międzynarodowego, Przegląd Stosunków Międzynarodowych 1990, nr 3-4.

Sozański J., Zakres udziału Zakonu Maltańskiego w stosunkach prawnomiędzynarodowych, Państwo i Prawo 1992, nr 9.

Sozański, Współczesne prawo traktatów, Warszawa-Poznań 2003.

Sozański J., Prawo traktatów: zarys współczesny, Warszawa 2008.

Sutor J., Prawo dyplomatyczne i konsularne, Warszawa 2003.

Szwejkowska M., Milkowski K., Suwerenny Zakon Kawalerów Maltańskich jako podmiot prawa międzynarodowego, Studia Prawnoustrojowe 2018, t. 38.

Thirlway H., The Sources of International Law, Oxford 2019.

Tyranowski J., Sukcesja państw a traktaty w sprawie granic, Poznań 1979.

Wierzbicki B., Prawo międzynarodowe, Białystok 2008.

Андреев А.Р., Захаров В.А., Настенко И.А., История Мальтийского Ордена, Москва 1999.

Гилязетдинов М.Р., Проблемы в понимании суверенитета и международно-правового статуса Суверенного Мальтийского ордена, Вестник Пермского института ФСИН России 2017, nr 2 (25.

Де Верто Р., История мальтийских рыцарей, Москва 2014.

Захаров В.А. Суверенный Мальтийский орден - европейская реальность или исторический рудимент?, Россия XXI 2002, nr 4.

Захаров В.А., Мальтийский орден как европейское государство, Современная Европа 2002, nr 2.

Захаров В.А., Мальтийский орден и его место в системе европейских государств, Вопросы истории 2006, $\mathrm{nr} 8$.

Игнатенко Г.В., Тиунов О.В., Международное право, Москва 2010.

Колосов Ю.М., Кривчикова Э.С., Иванов Д.В., Международное право, Москва 2000.

Лестев А.Е., Морально-нравственные императивы рыцарей Суверенного Военного Мальтийского Ордена, Этнология и Культурная Антропология 2015, nr 4 (28), DOI: $10.7256 / 2222-1956.2015 .4 .15204$.

Цацка И.П., О Суверенитете Духовно-Рыиарского Мальтийского Ордена, Вестник ОГУ 2013, nr 7 (156). 
